Original Article

\title{
Association of blood groups/Rh and diabetes mellitus in Karachi city, Pakistan
}

\author{
Associação de grupos sanguíneos/Rh e diabetes mellitus na cidade de Karchi, \\ Paquistão
}

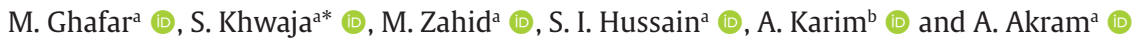 \\ aFederal Urdu University of Arts, Science, and Technology, Department of Zoology, Gulshan -e-Iqbal, Karachi, Pakistan. \\ 'Sardar Bahadur Khan Women's University, Department of Zoology, Quetta, Pakistan.
}

\begin{abstract}
The main purpose of this study was to find out a possible association between ABO blood groups or Rh and diabetes mellitus (DM) in the local population of eight (8) different towns of Karachi, Pakistan. For this purpose a survey was carried out in Karachi to have a practical observation of these towns during the period of 9 months from June 2019 to Feb. 2020. Out of eighteen (18) towns of Karachi, samples ( $N=584$ ) were collected from only eight (8) Towns of Karachi and gave a code-number to each town. Diabetic group sample was (n1=432) \& pre-diabetes sample was (n2 =152). A standard Abbot Company Glucometer for Random Blood Sugar (RBS) and Fasting Blood Sugar (FBS) tests, standard blood anti sera were used for $\mathrm{ABO} / \mathrm{Rh}$ blood type. Health assessment techniques were performed ethically by taking informed consent from all registered subjects. Finally data was analyzed by SPSS version 20.0. In our current study, the comparison of $\mathrm{ABO}$ blood groups frequencies between diabetic and pre-diabetic individuals were carried out. The percentage values of blood Group-B as given as: ( $32 \%$ in DM vs. $31 \%$ in pre-diabetics), followed by blood Group-O as: (18\% in DM vs. 11\% in pre-diabetics). Contrary to Group-"B" \& "O", blood Group-A and Group-AB were distribution percentage higher pre-diabetic as compared to DM patients, as given as: Group-A (32\% in prediabetics vs. $26 \%$ in DM) \& Group-AB (26\% in pre-diabetics vs. $24 \%$ in diabetic's patients). In addition, percentage distribution of Rh system was also calculated, in which Rh+ve Group was high and more common in DM patients as compared to pre-diabetics; numerically given as: $\mathrm{Rh}+\mathrm{ve}$ Group (80\% in DM vs. $72 \%$ in pre-diabetics). Different views and dimensions of the research topic were studied through literature support, some have found no any association and some established a positive association still some were not clear in making a solid conclusion. It is concluded that DM has a positive correlation with ABO blood groups, and people with Group-B have increased susceptibility to DM disease.
\end{abstract}

Keywords: ABO blood groups, Rh group, diabetes mellitus (DM), Pre-diabetes, T1DM, T2DM, GDM, Hyperglycemia.

\begin{abstract}
Resumo
O objetivo principal deste estudo foi descobrir uma possível associação entre grupos sanguíneos ABO ou Rh e diabetes mellitus (DM) na população local de oito (8) diferentes cidades de Karachi, Paquistão. Para tanto, foi realizado um levantamento em Karachi para observação prática dessas cidades durante o período de 9 meses de junho de 2019 a fevereiro de 2020.De dezoito (18) cidades de Karachi, as amostras $(\mathrm{N}=584)$ foram coletadas de apenas oito (8) cidades de Karachi e deram um número-código para cada cidade. A amostra do grupo de diabéticos foi $(n 1=432)$ e a amostra de pré-diabetes foi $(\mathrm{n} 2=152)$. Um glicômetro padrão da Abbot Company para testes de açúcar no sangue aleatório (RBS) e açúcar no sangue em jejum (FBS), antissoros de sangue padrão foram usados para o tipo de sangue $\mathrm{ABO} / \mathrm{Rh}$. As técnicas de avaliação de saúde foram realizadas de forma ética, tomando o consentimento informado de todos os indivíduos registrados. Finalmente, os dados foram analisados pelo SPSS versão 20.0.No presente estudo, foi realizada a comparação das frequências dos grupos sanguíneos $\mathrm{ABO}$ entre diabéticos e pré-diabéticos. Os valores percentuais do sangue do Grupo-B são dados como: (32\% em DM vs. 31\% em pré-diabéticos), seguido pelo sangue do Grupo-O como: (18\% em DM vs. 11\% em pré-diabéticos). Ao contrário dos Grupos "B" e "O", sangue do Grupo-A e Grupo-AB tiveram distribuição percentual maior de pré-diabéticos em comparação com pacientes com DM, dado como: Grupo-A ( $32 \%$ em pré-diabéticos vs. $26 \%$ em DM) e Grupo AB ( $26 \%$ em pré-diabéticos vs. $24 \%$ em pacientes diabéticos). Além disso, também foi calculada a distribuição percentual do sistema Rh, no qual o Grupo Rh + ve foi elevado e mais comum em pacientes com DM em comparação aos pré-diabéticos; dados numericamente como: Grupo Rh + ve (80\% em DM vs. $72 \%$ em pré-diabéticos). Diferentes visões e dimensões do tema de pesquisa foram estudadas com o suporte da literatura, alguns não encontraram nenhuma associação e alguns estabeleceram uma associação positiva, embora alguns não estivessem claros em fazer uma conclusão sólida. Conclui-se que o DM tem correlação positiva com os grupos sanguíneos $\mathrm{ABO}$, e as pessoas com o Grupo B têm maior suscetibilidade à doença DM.
\end{abstract}

Palavras-chave: grupos sanguíneos ABO, grupo Rh, diabetes mellitus (DM), pré-diabetes, DM1, DM2, DMG, hiperglicemia.

*e-mail: sobia.khwaja@fuuast.edu.pk; sobia.khawaja@hotmail.com

Received: June 4, 2021 - Accepted: October 10, 2021

This is an Open Access article distributed under the terms of the Creative Commons Attribution License, which permits unrestricted use, distribution, and reproduction in any medium, provided the original work is properly cited. 


\section{Introduction}

Diabetes is a metabolic disease that causes increased blood sugar level called hyperglycemia. Pathophysiology of DM, it can be classified into two common types. In type-I Diabetes Mellitus (TIDM) there is unavailability of insulin hormone in the patient's blood., insulin hormone is not available in the blood of type-I diabetic patients, to overcome this deficiency, insulin injection is necessary for the patient affected with T1DM. Therefore, T1DM was previously called Insulin Dependent Diabetes Mellitus (IDDM). In addition rather a new term Latent Autoimmune Diabetes of Adult (LADA) is a condition in which T1DM develops in adults are frequently initially undiagnosed as having T2DM, based on age rather than cause. In Type- 2 DM, pancreatic $\beta$-cells are capable to secrete enough amount of insulin hormone, but there is a defect at the receptor site, that hinders or resists in its function or physiology. In spite of presence of sufficient amount of insulin hormone in the blood, it is not working properly and cannot help blood glucose to enter into the cell or tissue. As a result, blood glucose level rises called hyperglycemia due to this insulin receptor blockage or resistance. T2DM ranges from relative deficiency of insulin secretion to insulin resistance. As Patient does not need insulin injection in T2DM; hence this type of DM was previously called as Non-Insulin Dependent Diabetes Mellitus (NIDDM) (Kumar et al., 2010). The majority of the 382 million people with diabetes are aged between $40-$ 59 and $80 \%$ of them are live in low-and middle-income countries. All types of DM are on the increase, Type 2 DM in particular: The number of people with diabetes will increase by $55 \%$ by 2035 (IDF, 2015).

In 1900, Karl Landsteiner (1900) discovered ABO blood group system and he also succeeded to identify four types of blood groups group $A$, group $B$, group $A B$, and group $O$ respectively. Each allelic form of $A B O$ blood groups is $A, B, A B$ and $O$ respectively, each of them has the responsibility to produce its own glycoprotein. The gene that is responsible for the determination of $\mathrm{ABO}$ blood type is present on chromosome number- 9 and is called ABO Glycosyltransferase (Sharma et al., 2014).

Since the discovery of ABO system by Karl Landsteiner in 1900 , many researchers took their interest to conduct their own research studies to find out any association of ABO blood group with diseases. Genetic Science have confirmed that some genetic factors are involved which cause Diabetes Mellitus (DM). Similar strong evidences do exist that $\mathrm{ABO} / \mathrm{Rh}$ blood systems are genetically determined as described earlier. Hence, DM and ABO/Rh blood system both have a common association/linkage with genetic integrations \& both have their respective genetic factors/ genes (Kumar et al., 2015).

Despite that some epidemiological studies discussed the linkage between $\mathrm{ABO}$ blood group and the risk of developing diabetes mellitus, but findings were not consistent and not yet clarified. Therefore, this study designed to evaluate the association between $\mathrm{ABO}$ blood group and diabetes mellitus.

\section{Materials and Methods}

The study was to conduct after the approval from the ethical committee of Federal Urdu University of Arts Science and Technology (FUUAST). Present study was conducted to identify a possible link between $\mathrm{ABO} / \mathrm{Rh}$ blood groups with DM among population residing in different towns of Karachi city, Pakistan. For this purpose, a nine-month survey was carried out starting from June, 2019 till Feb, 2020 for data collection. Karachi city has been divided into 18 different towns, from which we randomly selected eight (8) towns. Fifty four blood samples of DM both male and female were collected from randomly selected towns to check $\mathrm{ABO} / \mathrm{Rh}$ blood group. One fifty two samples of pre-diabetic individuals are included in this study. Then to each randomly selected town a specific code number (Table 1) was given to make it easy for computer data entry. Karachi Map with location of Towns as mentioned in the Figure 1.

\subsection{Inclusion criteria}

Diabetic and Pre-diabetic patients of Karachi from different ethnic groups e.g. Sindhi, Pathan, Punjabi, mahajar, Burhui, Sariki and Balochi etc. were included in the sample selection of the research study. Both genders i.e. Males and Females whose ages were from 40 to 70 years old were included in this study. In this research study we included diabetic patients regardless of its types and regardless of any ethnic group, religion, creed, color or race etc.

\subsection{Exclusion criteria}

All Non-Diabetic (below border line values) patients were excluded in sample collection. Similarly, all diabetic patients \& Pre-diabetic individuals, both males and females whose ages were less than 40 years and more than 70 years were also excluded from sample selection and were not the focus of this research study.

\subsection{Questionnaire as a data collection tool}

This questionnaire was comprised of different components necessary for data collection. One component was addressing the date related to participant's address, demographic data, height \& weight. The second component was concerning to participant's/respondent's family

Table 1. Name of selected towns and their code no.

\begin{tabular}{ccc}
\hline S.No. & Town Name & Code No. \\
\hline 1 & Kemari Town & 1 \\
2 & S.I.T.E Town & 2 \\
3 & Baldia Town & 3 \\
4 & Orangi Town & 4 \\
5 & Layari Town & 5 \\
6 & Saddar Town & 6 \\
7 & Jamshed Town & 7 \\
8 & Gulshan & 8 \\
\hline
\end{tabular}




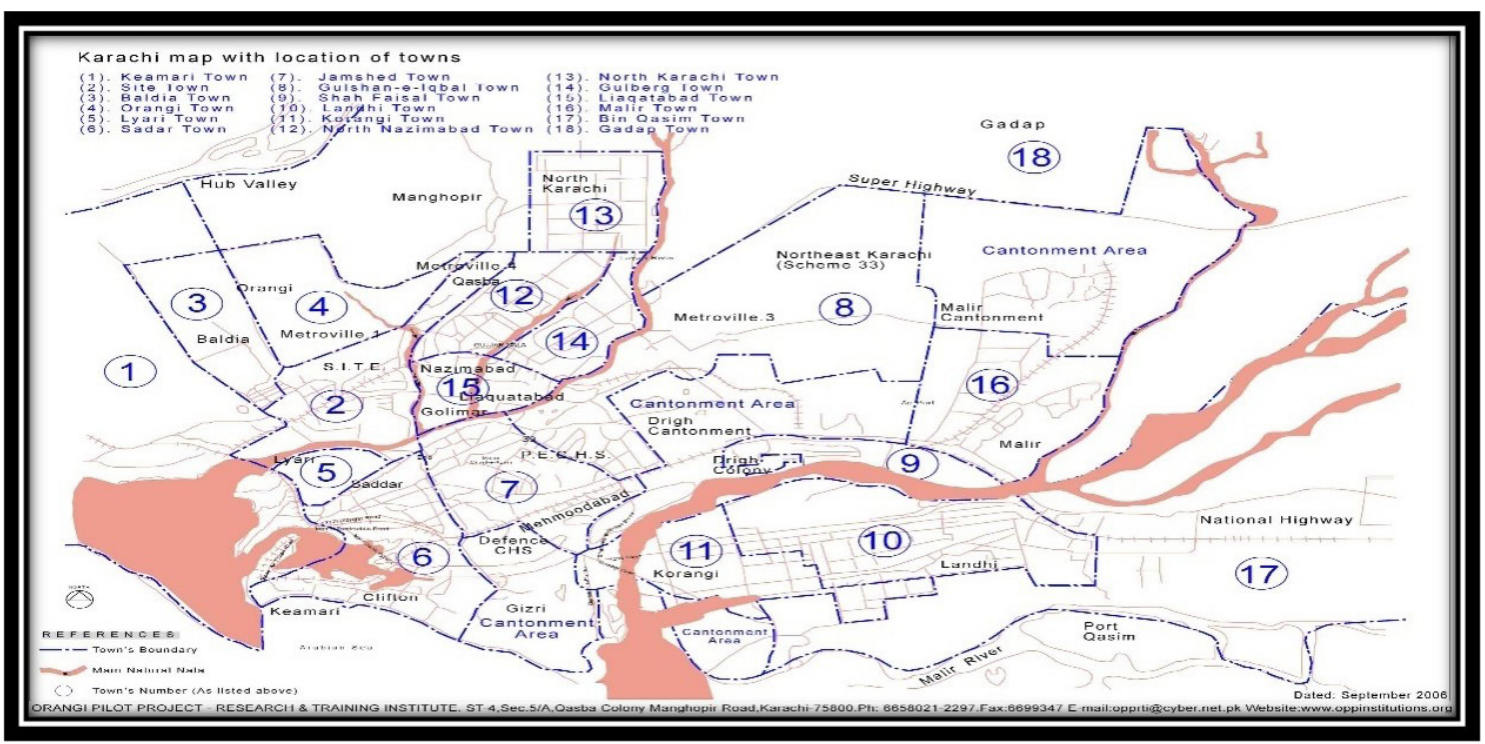

Figure 1. Showing Location of 18 different towns in Karachi.

history of Diabetes Mellitus (DM). The third component of questionnaire was related to participant's Blood/Rh groups' tests ( $\mathrm{ABO} / \mathrm{Rh}$ blood system) and blood glucose tests (RBS/ FBS tests).

\subsection{Informed consent}

During data collection at the field work, ethical considerations and principles were kept in mind to conduct a safe and ethically legal research study. The risk \& benefit of the research study was explained to all participants of the study and written informed consent was obtained irrespective of their age, gender, ethnicity or socio-economic status from all individuals enrolled in the research study. From each registered study participants a proper history was taken through interviewing. The subject was then thoroughly examined, performed tests required for research study and finally collected information data was recorded in a data schedule notebook.

\subsection{Data collection techniques}

A sample of $(\mathrm{N}=584)$ participants was collected from 8 different towns of Karachi city. From out of 18 towns we select eight towns and gave code number to each town as given in the Table 1 . Out of 584 participants, 432 were actually diabetic patients those were already diagnosed as Diabetes Mellitus (n1), and the remaining 152 were pre-diabetes/ borderline who apparently had high blood glucose level but were not fulfilling the criteria to be diagnosed as DM (n2). The samples were randomly collected from the general population as well as patients who were visiting local diabetic clinics available in the each town under study.

The blood glucose tests of study subjects both random blood sugar (RBS) or fasting blood sugar (FBS) were performed by a standard authentic blood glucose detecting-device or Glucometer made by the Abbot Company. However RBS or FBS were performed accordance to subject or patient availability and feasibility. Similarly, the $\mathrm{ABO}$ or Rh blood grouping tests were done according to the slide agglutination and antisera method; as described in the literature's leaflet by the maker of the high titer standardized commercial antisera company. The blood pressure (BP), height (ht.), weight (wt.), body mass index (BMI) variables were also measured under the guidance of standard assessment techniques and procedures.

\subsection{Validity \& reliability}

The data was confirmed from all participants and ensured its validity. A valid standard Glucometer of the Abbot Company was used. Glucometer is a device used for blood glucose tests (for both RBS \& FBS) was used to test participant's blood sugar level e.g. Random Blood Sugar (RBS $\geq 200 \mathrm{mg} / \mathrm{dl}$ ) and Fasting Blood Sugar (FBS $\geq 126 \mathrm{mg} / \mathrm{dl}$ ) in our research study.

Similarly, standard blood anti-sera were used for $\mathrm{ABO} / \mathrm{Rh}$ blood groups. Furthermore, if there found some doubt in RBS/FBS result values of a participant or if not remembering their blood type or group, then re-assessment and re-confirmation of the data was focused on to ensure the reliability of the data which was analyzed further through SPSS version 20.0

\section{Results}

According to our selected criteria, we had selected only those age group of people whose age was failing in the range between 40 to 70 years. If we compare the average age of DM with pre-diabetics observed minor differences between the two age groups. This difference reflects that pre-diabetics population will get or may get diabetes mellitus in near future (Table 2). Observed data of average height shows had no significant change or difference between two groups i.e. diabetes mellitus and 
pre-diabetics (Table 3). The calculated data given in the Table 4 shows no significant relation of weight between diabetes mellitus and pre-diabetics. Table 5. Illustrates a minor fluctuation in the average B.P value between DM and pre-diabetics group.
The average RBS of DM participants who were living in the eight different towns of Karachi, data illustrates that people who were living in Layari Town (code no. 05) had the highest average Random blood Sugar (RBS) $266 \mathrm{mg} / \mathrm{dl}$ among all eight different towns of Karachi, while both

Table 2. Average age of DM and Pre-diabetic individuals of eight towns.

\begin{tabular}{|c|c|c|c|c|c|c|c|c|c|c|}
\hline \multirow{2}{*}{$\begin{array}{l}\text { Town } \\
\text { Code \# }\end{array}$} & \multicolumn{5}{|c|}{ Diabetic } & \multicolumn{5}{|c|}{ Pre-Diabetic } \\
\hline & Mean & Mode & Median & SD & SE & Mean & Mode & Median & SD & SE \\
\hline 1 & 51.0 & 45 & 52 & 6.49 & 0.88 & 48 & 45 & 45 & 5.9 & 1.3 \\
\hline 2 & 49.7 & 45 & 50 & 7.13 & 0.97 & 51.8 & 56 & 56 & 8.5 & 1.9 \\
\hline 3 & 49.0 & 47 & 47.5 & 6.16 & 0.84 & 50.2 & 46 & 48 & 7.1 & 1.6 \\
\hline 4 & 56.8 & 55 & 55 & 9.29 & 1.26 & 66.3 & 80 & 66 & 9.6 & 2.2 \\
\hline 5 & 50.7 & 50 & 50 & 4.78 & 0.65 & 50.1 & 50 & 50 & 5.0 & 1.1 \\
\hline 6 & 51.5 & 53 & 52 & 4.15 & 0.56 & 50 & 49 & 49 & 4.0 & 0.9 \\
\hline 7 & 49.1 & 45 & 49 & 5.50 & 0.74 & 47.6 & 45 & 45 & 5.7 & 1.3 \\
\hline 8 & 51.9 & 50 & 51.5 & 3.84 & 0.52 & 54.0 & 55 & 54 & 3.4 & 0.7 \\
\hline Over all & 51.2 & 50 & 50 & 6.53 & 0.31 & 52.2 & 55 & 51 & 8.5 & 0.6 \\
\hline
\end{tabular}

\# = Number, $\mathrm{SD}=$ Standard deviation, $\mathrm{SE}=$ Standard error.

Table 3. Average height of DM and Pre-diabetic individuals of eight towns.

\begin{tabular}{|c|c|c|c|c|c|c|c|c|c|c|}
\hline \multirow{2}{*}{$\begin{array}{l}\text { Town } \\
\text { Code \# }\end{array}$} & \multicolumn{5}{|c|}{ Diabetic } & \multicolumn{5}{|c|}{ Pre-Diabetic } \\
\hline & Mean & Mode & Median & SD & SE & Mean & Mode & Median & SD & SE \\
\hline 1 & 5.5 & 5.5 & 5.5 & 0.15 & 0.02 & 5.5 & 5.5 & 5.5 & 0.20 & 0.04 \\
\hline 2 & 5.7 & 5.6 & 5.6 & 0.22 & 0.03 & 5.7 & 5.6 & 5.7 & 0.20 & 0.04 \\
\hline 3 & 5.4 & 5.9 & 5.4 & 0.44 & 0.06 & 5.4 & 5 & 5.2 & 0.42 & 0.09 \\
\hline 4 & 5.5 & 5.6 & 5.6 & 0.29 & 0.04 & 5.4 & 5 & 5.3 & 0.47 & 0.10 \\
\hline 5 & 5.5 & 5.6 & 5.6 & 0.17 & 0.02 & 5.5 & 5.4 & 5.5 & 0.18 & 0.04 \\
\hline 6 & 5.6 & 5.5 & 5.6 & 0.17 & 0.02 & 5.6 & 5.5 & 5.6 & 0.17 & 0.04 \\
\hline 7 & 5.4 & 5.4 & 5.5 & 0.19 & 0.02 & 5.5 & 5.5 & 5.5 & 0.23 & 0.05 \\
\hline 8 & 5.4 & 5.4 & 5.4 & 0.16 & 0.02 & 5.4 & 5.3 & 5.5 & 0.16 & 0.03 \\
\hline Over all & 5.5 & 5.6 & 5.5 & 0.2 & 0.1 & 5.5 & 5.5 & 5.5 & 0.3 & 0.02 \\
\hline
\end{tabular}

\# = Number, $\mathrm{SD}=$ Standard deviation, $\mathrm{SE}=$ Standard error.

Table 4. Average weight of DM and Pre-diabetic individuals of eight towns.

\begin{tabular}{|c|c|c|c|c|c|c|c|c|c|c|}
\hline \multirow{2}{*}{$\begin{array}{c}\text { Town } \\
\text { Code \# }\end{array}$} & \multicolumn{5}{|c|}{ Diabetic } & \multicolumn{5}{|c|}{ Pre-Diabetic } \\
\hline & Mean & Mode & Median & SD & SE & Mean & Mode & Median & SD & SE \\
\hline 1 & 79.3 & 80 & 80 & 7.8 & 1.1 & 80 & 80 & 80 & 9.1 & 2.1 \\
\hline 2 & 77 & 82 & 80 & 9.4 & 1.1 & 74 & 68 & 72 & 6.5 & 1.5 \\
\hline 3 & 72 & 70 & 72 & 9.4 & 1.1 & 77 & 70 & 75 & 12 & 2.7 \\
\hline 4 & 86 & 80 & 87.5 & 14 & 1.9 & 80 & 95 & 82 & 12.7 & 3 \\
\hline 5 & 80 & 82 & 81 & 7.3 & 1 & 75 & 76 & 78 & 12.4 & 2.8 \\
\hline 6 & 81 & 78 & 80 & 6.4 & 1 & 77 & 75 & 78 & 8 & 1.8 \\
\hline 7 & 83 & 80 & 82 & 7.2 & 1 & 84 & 80 & 85 & 13.2 & 3.2 \\
\hline 8 & 80 & 80 & 80.5 & 6.1 & 0.8 & 81 & 78 & 80 & 6.6 & 1.5 \\
\hline Over all & 79.8 & 80 & 80 & 9.5 & 0.5 & 79 & 80 & 80 & 10.6 & 0.8 \\
\hline
\end{tabular}

\# = Number, $\mathrm{SD}=$ Standard deviation, $\mathrm{SE}=$ Standard error 
Table 5. Average BP of DM and Pre-diabetic individuals of eight towns.

\begin{tabular}{|c|c|c|c|c|c|c|}
\hline \multirow{2}{*}{ Town Code \# } & \multicolumn{3}{|c|}{ Diabetic Mellitus Systolic/Diastolic } & \multicolumn{3}{|c|}{ Pre-Diabetic Systolic/Diastolic } \\
\hline & Mean & SD & SE & Mean & SD & SE \\
\hline 1 & $141 / 88$ & $11 / 6$ & $1.5 / 0.5$ & $137 / 87$ & $10 / 6$ & $2.3 / 1.4$ \\
\hline 2 & $141 / 89$ & $12 / 9$ & $1.6 / 1.2$ & $137 / 89$ & $7.5 / 4$ & $1.7 / 1$ \\
\hline 3 & $126 / 83$ & $11 / 9$ & $1.5 / 1.2$ & $134 / 87$ & $10.7 / 7.3$ & $2.5 / 1.7$ \\
\hline 4 & $138 / 90$ & $20 / 11$ & $2.7 / 1.5$ & $149 / 90$ & $28 / 11.3$ & $6.5 / 2.6$ \\
\hline 5 & $144 / 88$ & $8 / 5$ & $1.1 / 0.7$ & $139 / 89$ & $8.7 / 5.7$ & $2 / 1.3$ \\
\hline 6 & $146 / 89$ & $9 / 5.2$ & $1 / 0.7$ & $140 / 88$ & $8 / 4$ & $1.6 / 1$ \\
\hline 7 & $142 / 87$ & $8 / 6.4$ & $1.1 / 1$ & $142 / 87$ & $11 / 9$ & $2.5 / 2.1$ \\
\hline 8 & $143 / 87$ & $7 / 5.8$ & $0.8 / 1$ & $137 / 83$ & $8.7 / 4.7$ & $2 / 1$ \\
\hline Over all & $140 / 87$ & $13 / 7.7$ & $0.4 / 0.6$ & $139 / 88$ & $13.6 / 8.4$ & $1.1 / 0.7$ \\
\hline
\end{tabular}

\# = Number, $\mathrm{SD}=$ Standard deviation, $\mathrm{SE}=$ Standard error.

Jamshed (code. 07) \& Gulshan-e-Iqbal towns (code no. 08) sample population with diabetes mellitus (DM) had the second highest average Random blood Sugar (RBS) which was $262 \mathrm{mg} / \mathrm{dl}$. The minimum average RBS among diabetes mellitus (DM) patients were found in the Baldia town (code no. 03) that was $187 \mathrm{mg} / \mathrm{dl}$. But overall in all eight different towns of Karachi. The average Random blood Sugar (RBS) distribution among total population was approximately $246 \mathrm{mg} / \mathrm{dl}$. Similarly the average RBS in Pre-diabetics individuals who were living in eight different towns of Karachi. The data of pre-diabetic persons who were residence of Saddar Town (code no. 06) had the highest average RBS (190 mg/dl), while the second highest average RBS in pre-diabetic individuals that were living in Baldia town (code no.3) was found to be $185 \mathrm{mg} / \mathrm{dl}$. However, S.I.T.E's town (code no. 02) population with pre-diabetics had the lowest average RBS (152 mg/dl). Persons with pre-diabetic had an average $176 \mathrm{mg} / \mathrm{dl}$ RBS in overall population. This difference of average RBS reflects that pre-diabetics population was at high risk to be diabetic patients in coming year or near future. Over all distribution of Blood groups in all eight towns of Karachi were as; $(A+=87),(A-=26),(B+=118),(B-=20)$, $(\mathrm{AB}+=84),(\mathrm{AB}-=22),(\mathrm{O}+=56)$ \& blood group $(\mathrm{O}-=19)$ recorded respectively. The above values of $A B O \& R h$ blood depict that blood group $(B+=118$ ) was noted to be the highest group in $\mathrm{ABO} / \mathrm{Rh}$ blood group system while blood group ( $A+=87$ ) which was the second highest or intermediate group in $\mathrm{ABO} / \mathrm{Rh}$ blood group system and blood group was noted as $(A B+=84)$ which stood at third place or low level among total population. Finally, the least or the lowest common blood groups among all participants $(\mathrm{N}=432)$ in the research study were blood group $(\mathrm{O}-=19)$ \& blood group (B- $=20$ ) respectively. Thus blood group (O-) which was equal to 19 was the lowest number in selected towns of Karachi city (Table 6).

According to central tendency theory, values of mean, mode \& median always fall in the center of bell shaped diagram which reflects average normal distribution of sample population. Table 4 shows overall average distribution of $\mathrm{ABO}$ and $\mathrm{Rh}$ blood groups among different towns of Karachi, the highest values showed was present in blood group $(B+=118)$ of diabetic patients and percentage was $27.3 \%$ in Blood group B in all eight towns of Karachi.

Similarly, the second intermediate/middle highest values in Table 4 of $\mathrm{ABO} / \mathrm{Rh}$ blood groups was blood group $A(A+=87)$. The second last minimum values in $\mathrm{ABO} / \mathrm{Rh}$ blood group was $(\mathrm{B}-=20)$. The last lowest or the minimum mean values in $\mathrm{ABO} / \mathrm{Rh}$ blood group was blood group $(\mathrm{O}-=19)$ and percentage $=4.3 \%$ respectively in all eight (08) different towns of Karachi city of Pakistan.

The individual random distribution of $\mathrm{ABO}$ and $\mathrm{Rh}$ blood group system in each town in pre-diabetic patients who were living in the eight (8) different towns of Karachi, according to data equal number (19) of pre-diabetic persons (without gender selectivity) were randomly selected from each town of Karachi those were not previously diagnosed as diabetes mellitus (DM) and were called pre-diabetics.

Similarly, overall total distribution of $A B O$ and $\mathrm{Rh}$ blood groups in pre-diabetic participants, along with other parameters have also been given in Table 6 which were: blood group $\left(A^{+}\right)=37,\left(A^{-}\right)=12,(B+)=33$, $(B-)=14,(A B+)=30,(A B-)=09,(O+)=09$ \& blood group $(\mathrm{O}-)=07$ respectively. It means that the highest common group in ABO \& Rh blood groups system was A+ (37) with $24 \%$, the second highest common blood group was $(B+)=33$ with $21 \%$ while the least common blood group among pre-diabetic clients in eight different towns of Karachi was (O-) $=07$ with $4.6 \%$ as displayed in Table 6 .

The contingency table (6) shows that the Observed frequencies (fo) of $\mathrm{Rh}$ group was higher in diabetic patients because of the larger random sample $(n 1=432)$ than Pre-diabetic random sample ( $\mathrm{n} 2=152$ ). However, the Observed frequency (fo) of Rh+ve groups was higher [Rh+ve $=345(79 \%)]$ in DM group than Rh-ve diabetics patients [Rh-ve $=87(21 \%)$ ]. Overall diabetics sample $(\mathrm{n} 1=432)$ collected randomly from eight different sites of Karachi (Table 7).

The Expected frequencies ( $f e$ ) of Rh group was higher in diabetics because of larger random sample ( $1=432$ ) than Pre-diabetic sample ( 2 = 152). However, the Expected frequency ( $f e$ ) of Rh+ve groups group was higher within 
Table 6. Distribution of $\mathrm{ABO}$ and Rh groups in DM and Pre- diabetics in 8 towns.

\begin{tabular}{|c|c|c|c|c|c|c|c|c|c|c|}
\hline $\begin{array}{c}\text { Code } \\
\text { No. }\end{array}$ & Groups & $A+$ & A- & B+ & B- & $\mathrm{AB}+$ & AB- & $0+$ & 0- & Total \\
\hline \multirow[t]{2}{*}{1} & DM & 9 & 5 & 15 & 3 & 9 & 3 & 5 & 5 & 54 \\
\hline & Pre-Diabetic & 5 & 2 & 4 & 1 & 4 & 1 & 1 & 1 & 19 \\
\hline \multirow[t]{2}{*}{2} & DM & 15 & 0 & 15 & 2 & 10 & 3 & 6 & 3 & 54 \\
\hline & Pre-Diabetic & 4 & 3 & 4 & 1 & 3 & 2 & 0 & 2 & 19 \\
\hline \multirow[t]{2}{*}{3} & DM & 12 & 3 & 13 & 4 & 9 & 4 & 7 & 2 & 54 \\
\hline & Pre-Diabetic & 4 & 2 & 3 & 3 & 3 & 1 & 3 & 0 & 19 \\
\hline \multirow[t]{2}{*}{4} & DM & 16 & 0 & 16 & 0 & 12 & 0 & 9 & 1 & 54 \\
\hline & Pre-Diabetic & 7 & 0 & 5 & 0 & 5 & 0 & 0 & 2 & 19 \\
\hline \multirow[t]{2}{*}{5} & DM & 10 & 4 & 14 & 3 & 10 & 5 & 6 & 2 & 54 \\
\hline & Pre-Diabetic & 6 & 0 & 5 & 2 & 3 & 1 & 3 & 0 & 19 \\
\hline \multirow[t]{2}{*}{6} & DM & 8 & 4 & 15 & 3 & 11 & 3 & 8 & 2 & 54 \\
\hline & Pre-Diabetic & 3 & 2 & 5 & 2 & 4 & 2 & 0 & 1 & 19 \\
\hline \multirow[t]{2}{*}{7} & $\mathrm{DM}$ & 8 & 4 & 17 & 1 & 12 & 2 & 8 & 2 & 54 \\
\hline & Pre-Diabetic & 4 & 2 & 3 & 3 & 3 & 1 & 2 & 1 & 19 \\
\hline \multirow[t]{2}{*}{8} & DM & 9 & 6 & 13 & 4 & 11 & 2 & 7 & 2 & 54 \\
\hline & Pre-Diabetic & 4 & 1 & 5 & 2 & 5 & 1 & 1 & 0 & 19 \\
\hline
\end{tabular}

Table 7. Observed frequencies $\left(f_{0}\right)$ of Rh groups in DM and Pre-diabetic.

\begin{tabular}{cccc}
\hline Rh group & DM $\left(f_{o}\right)$ & Pre-diabetes $\left(f_{o}\right)$ & Total $\left(f_{o}\right)$ \\
\hline Rh positive & 345 & 110 & 455 \\
Rh negative & 87 & 42 & 129 \\
Total & $432(\mathrm{n} 1)$ & $152(\mathrm{n} 2)$ & $584(\mathrm{~N})$ \\
\hline
\end{tabular}

Table 8. Expected frequencies $\left(f_{e}\right)$ of Rh groups in DM and Pre-diabetic.

\begin{tabular}{cccc}
\hline Rh group & DM $\left(f_{\mathrm{e}}\right)$ & Pre-diabetes $\left(f_{\mathrm{e}}\right)$ & Total $\left(f_{\mathrm{e}}\right)$ \\
\hline Rh positive & 337 & 118 & 455 \\
Rh negative & 95 & 34 & 129 \\
Total & $432(\mathrm{n} 1)$ & $152(\mathrm{n} 2)$ & $584(\mathrm{~N})$ \\
\hline
\end{tabular}

diabetic individuals $(\mathrm{Rh}+\mathrm{ve}=337)$ than $\mathrm{Rh}$-ve diabetics (Rh-ve $=95)$ Overall diabetics sample $(\mathrm{n} 1=432)$ collected randomly from eight different locations of Karachi (Table 8).

In a nutshell, we say that among all ABO blood Groups; Group-B is the highest in percentage distribution in diabetes mellitus (DM) group as compared to pre-diabetic group. The percentage values of blood Group-B in diabetic group versus pre-diabetic group as given as: blood Group-B (32\% in DM vs.31\% in pre-diabetics), followed by blood Group-O ( $18 \%$ in DM vs. $11 \%$ in pre-diabetics). Our current study concludes that individuals with blood Group-B are more likely to have DM, whereas a blood Group-O is less likely to have DM. Contrary to blood Group-B and Group-O, blood Group-A and Group-AB both were higher in Percentage distribution in pre-diabetic clients as compared to DM patients, as give as: blood Group-A (32\% in pre-diabetics vs. $26 \%$ in DM), followed by blood Group-AB (pre-diabetics $26 \%$ vs. $24 \%$ diabetic's patients). In addition to ABO blood Groups, percentage distribution of Rh system was also calculated, which showed high percentage distribution of $\mathrm{Rh}+\mathrm{ve}$ group high and was more common in DM patients as compared to pre-diabetics clients: numerically as shown as Rh+ve Group (80\% in DM vs. $72 \%$ in pre-diabetics).

\section{Discussion}

Several researchers have tried with their extensive studies to investigate a possible association between $\mathrm{ABO}$ and Rh blood Groups and diabetic mellitus (DM). 
But we found different views of different researchers in their studies, related to association of blood groups or Rh with DM.

In the literature review we found that different results have been proved as unclear, variant and inconsistent from one study to another study, from one country to another country, from one region to another region or even from one city to another city. Ganesan and Gani (2014) pointed out in their article that there was a significant difference between healthy subjects and diabetic patients in blood group B and Rh positive groups.

Although, some researchers have found some relationship but they were not so clear in their conclusion. Researchers have described that $A B$ blood group was significantly more frequent in type $1 \mathrm{DM}$ and blood group A was more frequent in type 2 DM. They further also highlighted that the frequency of Rh -ve was significantly more frequent in diabetics as compared to the control group in their studied population. They argued their view point that the mechanism with which $A B O$ or $R h$ blood groups affect diabetes mellitus (DM) was poorly understood (Oner et al., 2016)

In contrast, there are some studies available which have not shown any constant relationship in a particular blood group and could not succeed to establish any association between $\mathrm{ABO}$ or Rh blood groups with DM. A study conducted in Algeria shows blood groups did not differ significantly between the type 2 DM patients and the control subjects in the Algerian population (Dali et al., 2011).

Another study finding revealed that there is a positive interrelation between the blood groups and DM study was conducted in Qatar, shows an association between ABO blood group and diabetes mellitus (DM). They have argues with supportive literatures and concluded that blood group B was significantly more common in diabetic patients as compared to healthy population. Further they have concluded frequency of blood group-B was significantly high in diabetic male and among females the frequency of both blood group-A and blood group-B was significantly higher as compared to non-diabetic healthy population. Bener \& Yousafzai have concluded that ABO antigens were associated with diabetes mellitus (DM). DM was more common in individuals with blood group-B (Bener and Yousafzai, 2014). Our findings are similar to Kamil et al., (2010) they described blood group-A was less common as in our current study and shows negative association DM.

Sharma et al. (2014) reported in his results findings of their studied that was conducted in Jodhpur city of Rajasthan to evaluate the relationship of ABO blood groups with DM. Sharma and his colleague have shown negative association and have concluded that there was no association existed ABO blood groups and any type of DM.

We do have some evidences to support our current findings, Bener and Yousafzai (2014) have established a positive relationship and have suggested that $\mathrm{ABO}$ blood Antigens are associated with diabetes mellitus (DM). In their study findings, blood group-B was more common in DM patients as compared to pre-diabetic group.

Two other studies have been carried out by two different researchers one study conducted in Malaysia (Kamil et al., 2010) and the other study was conducted by Jaggi and
Yadav (2014) in India. These studies also have reported similar findings of higher frequency of blood group-B among diabetic patients.

Besides above foreigner's investigator's results findings, Qureshi and Bhatti (2003) from Pakistan also have demonstrated an association of higher frequency of blood group-B in DM as compared to pre-diabetics individuals. Meo et al. (2016) have established positive association of $\mathrm{ABO} / \mathrm{Rh}$ blood groups with $\mathrm{DM}$ and showed increased frequency of blood group-B followed by blood group-O in diabetic patients.

On contrary, a study conducted in Pakistan revealed that blood group $\mathrm{AB}$ was more frequent in diabetes than blood group-A and blood group-B. Studies regarding the association between $\mathrm{ABO}$ blood groups and DM are inconclusive. While some of the studies reported an evidence against the presence of any association existing between $\mathrm{ABO}$ and $\mathrm{DM}$. The possible explanation of conflicting results regarding the association between ABO blood groups and DM could be racial and geographical variations playing role in the genetic expression of the disease. Previous study has reported that the frequency of ABO blood group vary across different populations with respect to gender.

\section{Conclusion}

It is concluded that DM has some association $\mathrm{ABO}$ blood groups, and people with Group-B have increased susceptibility to DM disease. However, these findings are not significant to decide a solid conclusion. This may have some other genetic factors which may need further extensive and elaborative investigation.

\section{References}

BENER, A. and YOUSAFZAI, M.T., 2014. The distribution of the ABO blood groups among the diabetes mellitus patients. Nigerian Journal of Clinical Practice, vol. 17, no. 5, pp. 565-568. http:// dx.doi.org/10.4103/1119-3077.141418. PMid:25244264.

DALI, S.M., AOUR, M.A., BELMOKHTAR, F., BELMOKHTAR, R. and BOAZZA, F., 2011. The relationship between $\mathrm{ABO} /$ rhesus blood groups and type 2 diabetes mellitus in Maghnia, western Algeria. South African Family Practice, vol. 53, no. 6, pp. 568-572. http:// dx.doi.org/10.1080/20786204.2011.10874154.

GANESAN, K. and GANI, S.B., 2014. Relationship between ABO, Rh blood groups and diabetes mellitus, obesity in Namakkal town, Tamilnadu. International Journal of Advances in Pharmacy, Biological Chemistry, vol. 3, no. 4, pp. 995-998.

INTERNATIONAL DIABETES FEDERATION - IDF, 2015. IDF Diabetes Atlas. 7th ed. Brussels, Belgium: IDF.

JAGGI, S. and YADAV, A.S., 2014. Distribution of ABO and Rh (D) Allele frequency among the type 2 Diabetes Mellitus patients. American International Journal of Research in Formal, Applied \& Nature and Science, vol. 1, pp. 24-26.

KAMIL, M., ALI NAGI AL-JAMAL, H. and MOHD YUSOFF, N., 2010. Association of $\mathrm{ABO}$ blood groups with diabetes mellitus. The Libyan Journal of Medicine, vol. 5, no. 1, pp. 1-4. http://dx.doi. org/10.3402/ljm.v5i0.4847. PMid:21483592. 
KUMAR, P.R., BHANSALI, A., RAVIKIRAN, M., BHANSALI, S., DUTTA, P., THAKUR, J.S., SACHDEVA, N., BHADADA, S.K. and WALIA, R., 2010. Utility of glycated hemoglobin in diagnosing type 2 diabetes mellitus: a community-based study. The Journal of Clinical Endocrinology \& Metabolism, vol. 95, no. 6, pp. 28322835. https://doi.org/10.1210/jc.2009-2433.

KUMAR, V., ABBAS, A.K., and ASTER, J.C., 2015. Robbins \& Cotran Pathologic Basis of Disease. 9th ed. USA: Elsevier.

LANDSTEINER, K., 1900. Zur Kenntnis der antifermentativen, lytischen und agglutinierenden Wirkungen des Blutserums und der Lymphe. Zentralblatt fur Bakteriologie, vol. 27, pp. 357-362.

MEO, S.A., ZIA, I., BUKHARI, I.A. and ARAIN, S.A., 2016. Type 2 diabetes mellitus in Pakistan: Current prevalence and future forecast. The Journal of the Pakistan Medical Association, vol. 66, no. 12, pp. 1637-1642.

ÖNER, C., DOĞAN, B., TELATAR, B., ÇELIK YAĞAN, C.F. and OĞUZ, A., 2016. Frequency of $A B O /$ Rhesus blood groups in patients with diabetes mellitus. Journal of the College of Physicians and Surgeons Pakistan, vol. 26, no. 1, pp. 74-75.

QURESHI, M.A., and BHATTI, R., 2003. Frequency of ABO blood groups among the diabetes mellitus type 2 patients. Journal of the College of Physicians and Surgeons Pakistan, vol. 13, no. 8, pp. 453-455.

SHARMA, S., KUMAR, J., CHOUDHARY, R. and SONI, N.D., 2014. Study of association between $\mathrm{ABO}$ blood groups and diabetes mellitus. Scholars Journal of Applied Medical Sciences, vol. 2, no. 1A, pp. 34-37. 